\title{
From Ultima Thule to the Hellespont - Some remarks on the bone points of the Iron Age
}

\section{Jes Martens}

\begin{abstract}
Asbtract
Taking the outset in two finds of bone points in Norway, the distribution and use of the artefact type is discussed. Points of bone and antler are frequently found at settlements and in wetlands in Northern Europe. However, the exact distribution of the artefact type is hard to determine because its modest design makes it easy to overlook. This is also the reason why it is usually looked upon as a sign of poverty and as second rate. It seems the artefact type had more than one area of use; as a tool, as an implement for fishing and hunting, and as a combat weapon. Concerning the latter, it is argued that the points of bone and antler were valued and efficient weapons that more likely served as spears rather than javelins. This is confirmed by ancient written sources.
\end{abstract}

Keywords: Pre-Roman Iron Age, Bone Points, Antler Points, Weaponry, Spears.

A numerous but easily overlooked artefact type is the bone or antler point. A very simple looking artefact usually made from a hollowed out tibia of a sheep, cut at right angles in one end and diagonally in the other, quite often with a rivet hole at the base. They occur all over northern Central Europe, the British Isles and in the southern part of the Scandinavian Peninsula, in settlements, in graves and in wetlands. Their dating is wide, but the majority seems to be dating to the Pre-Roman Iron Age, i.e. the last half of the first millennium BC. Depending on their context, different uses have been inferred; tool, hunting or fishing implement, or weapon. Due to their crude design and cheap raw material, the artefacts are often considered an expression of shortage of metal and as a cheap and disposable solution. This obviously has consequences for the interpretation, but the question is whether this is paying the artefacts their due respect. Taking the outset in some so far overlooked specimens from Norway, this paper will focus on the function of these artefacts.

\section{Distribution}

The distribution of the artefact type is a bit tricky, and it is uncertain whether the known distribution (Schatte 2013, figs. 14-15) reflects the factual. It is easier to state with certainty where it occurs than where it does not occur. One important factor is the conditions for preservation. Artefacts of bone and antler are most likely to be preserved in regions and context with low acidity in the 


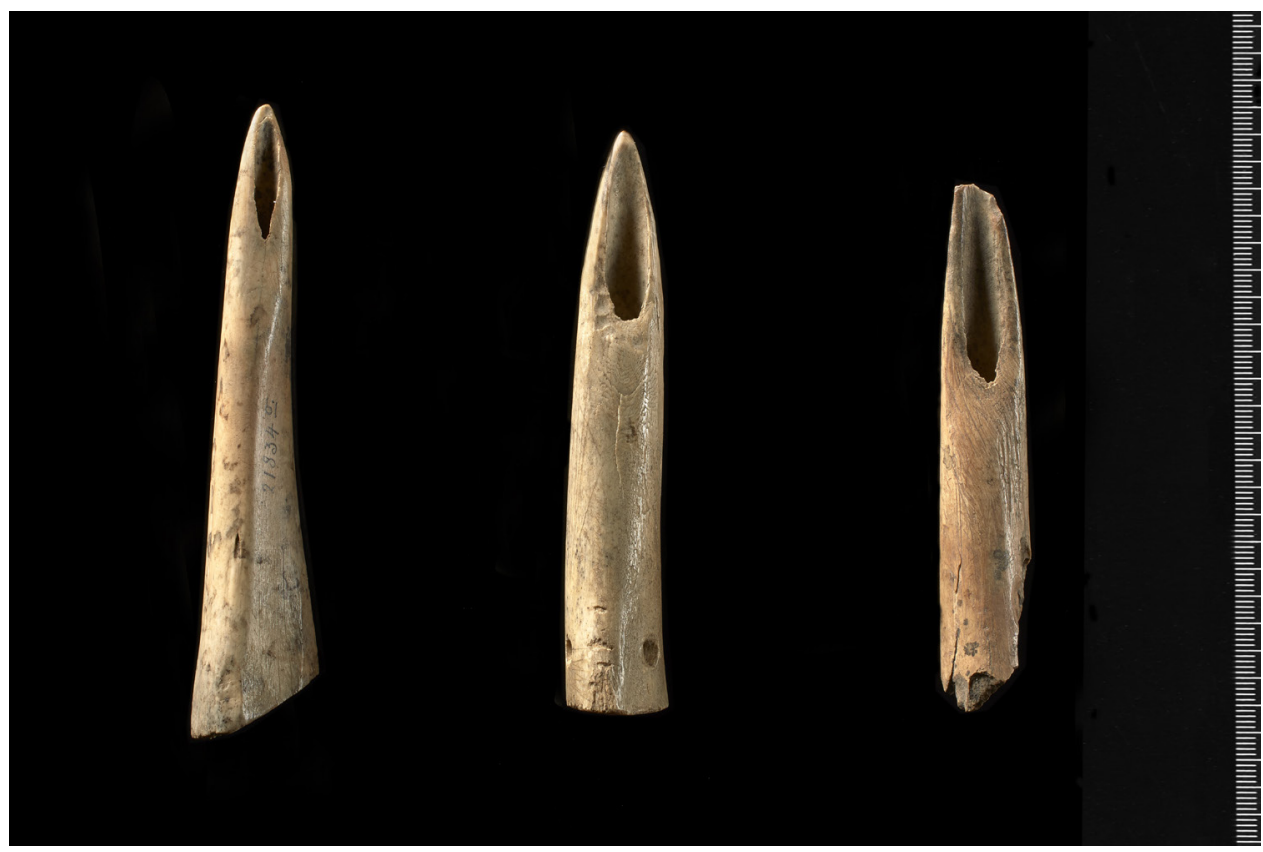

Fig. 1. The three bone points from Skjonghelleren, Møre og Romsdal (photo Kirsten J. Helgeland, Museum of Cultural History, University of Oslo).

ground as is the case in Eastern Denmark and Scania. Probably just as important a factor is the simplicity of the design. If no one pays particular attention to the artefact type, it may easily be overlooked or classified as a large needle or an awl. Therefore the bone points are particularly numerous in areas where researchers have given them special attention, like in Denmark, starting with the work of Hans Kjær (1901), in Mecklenburg where Ulrich Schoknecht (1982) recorded them, in Scania (Althin 1951), and in England (Olsen 2003 for references). Outside these areas, the presence or absence of the artefact is less well documented.

One of these areas is Norway. When I first dealt with the type (Martens 2001), I was not aware of any finds known from Norway, and it was only when I accidentally noticed three such points in the Iron Age exhibition of the $\mathrm{Mu}$ seum of Cultural History in Oslo that I realized that they also occur in this part of the world. I have later tried to check whether there are more, but it is a difficult task, since the museum storages of Norwegian museums are not open to researchers, and you have to order the artefacts you want to study. Thus a misclassified artefact is really difficult to look up.

The three specimens from the exhibition in Oslo stem from Skjonghelleren (Fig. 1; 2a-c), a rock-shelter on the island Valderøya near Ålesund on the Norwegian west-coast. The site was excavated in 1875 and published by Anton 


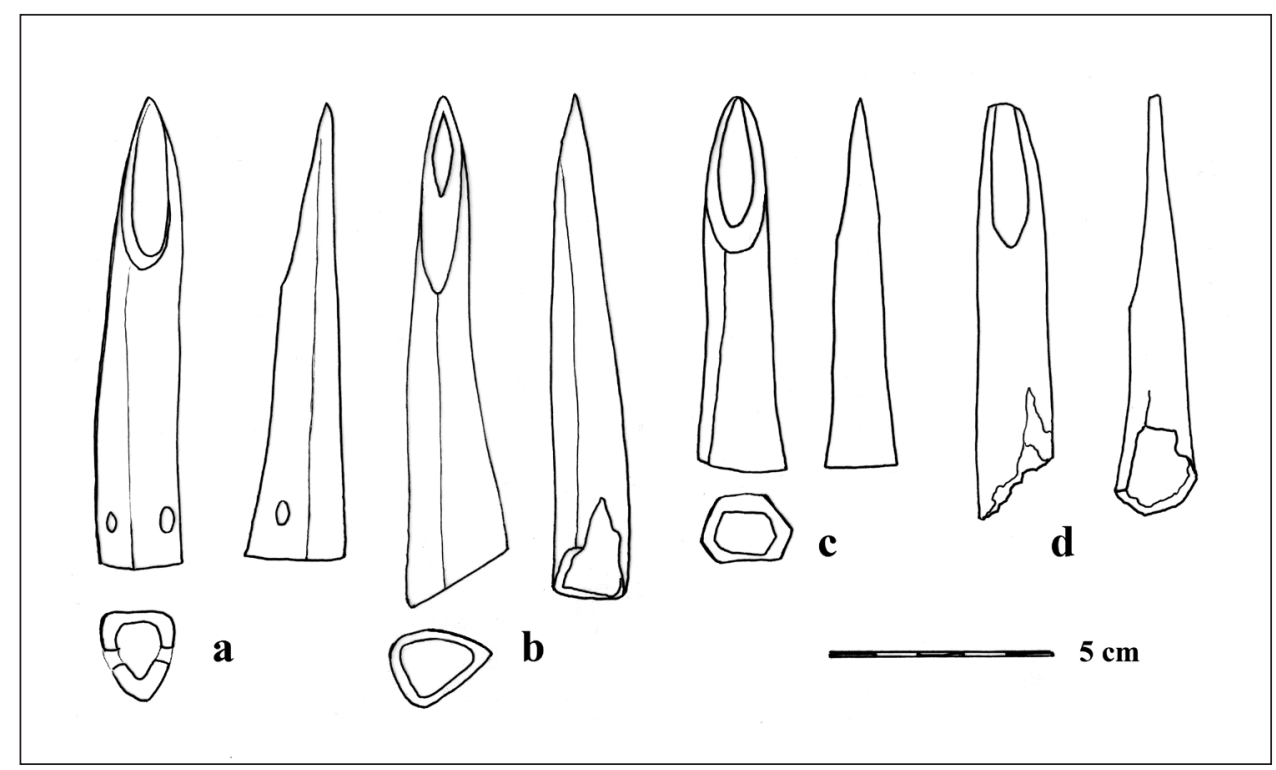

Fig. 2. The four known bone points from Norway - a-c Skjonghelleren (Museum of Cultural History, Oslo, C21834), d Havnhelleren (Museum of Cultural History, Oslo, C21848), (drawings V.V. \& J.Martens).

Wilhelm Brøgger in 1910. Brøgger recognized a number of bone points among the large material of animal bones and ascribed them to the type which Kjær had dealt with in detail a few years before (Brøgger 1910, 13-14, fig. 16). Brøgger also mentioned a further bone point (Fig. 2d) from another rock-shelter, Havnsundhelleren (Brøgger 1910, 17). Along with these points a number of arrow heads and an iron spearhead were found, in addition to a number of tools and pottery.

In 1911, Anders Nummedal carried out excavations in two rock-shelters, Gjeithelleren and Sauehelleren, on the island Bjørnerem not far from the aforementioned shelters. The relatively large bone material from these two excavations was sent to Herluf Winge in Copenhagen for analysis. The bones came from fish, land and sea mammals, a large variety of wild birds in combination with bones of domesticated animals, 55 different species in all. Among the bones Winge recognized a possible bone point (Fig. 3), but Nummedal himself was uncertain whether to interpret the artefact as a spear head or a bodkin (Nummedal 1913, 31, fig. 9b). The fact that the sides of the point of this specimen are concave in opposition to the usual convex shape supports his doubt. This is most likely a

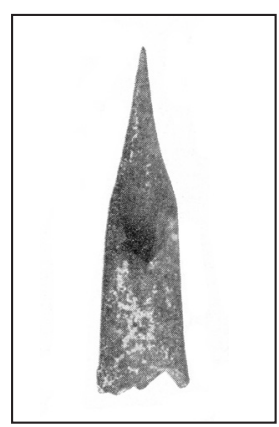

Fig. 3. Bone point from Sauehelleren, Møre og Romsdal (after Nummedal 1913, fig. 9b). 
bodkin. After this, no new finds have been published. The rock-shelters with the bone points date from the Late Roman Iron Age (Skjonghelleren and Havnsundhelleren) and the Migration Period (Sauehelleren).

While Brøgger interpreted the rock-shelters as places of refuge during unruly times, Nummedal rather understood them as settlements with a mixed economy, combining agriculture and husbandry with hunting. This he based on the large number of bones of game and fish in the archaeological deposits in the shelters. Since then our knowledge of the regular settlement sites of the Iron Age has grown considerably. Therefore Nummedal's interpretation has gained the upper hand, and the shelters can now be understood as hunting stations (for a modern survey of the Norwegian rock shelters see Bergsvik 2017). Furthermore, the predominant type of weapons found in the shelters was arrows, which could also indicate hunting. Thus even the bone points found in these shelters may have been part of this activity.

\section{Function}

This brings us to the function of these bone points. As mentioned in the introduction, a large number of the bone points have been found at settlements. This is especially the case in Denmark and in the British Isle, but also in the Netherlands and on Feddersen Wierde in Northern Germany. This naturally leads to an interpretation of the points as tools. Thus in English literature they are often referred to as gouges. However, experiments as well as studies on wear demonstrate that this is not a likely area of use, and neither is hide-scraper (Olsen 2003, 107-108). Another possible interpretation is that they served as awls, and more specifically as lip-work awls (Roes 1963, 36-37; Haarnagel 1979, 289), but even this interpretation is, according to Olsen, less likely at least when dealing with the completely hollowed out specimens. Olsen also considered several other suggested areas of use but rejected them because the points obviously were designed to be mounted on a wooden shaft. However, Olsen refers to a find where bone points were found in association with loom weights, indicating that these particular specimens may have served a function in relation to weaving. At other settlements such as Maiden Castle, Olsen points to the defensive nature of the sites what would seem to favour a martial interpretation of the artefacts (Olsen 2003, 108-110).

The furnishing of graves often reflects the tools and weaponry of their time, but unfortunately only a few are known which are furnished with bone points. The reason for this may be that cremation was the predominant burial rite in Northern Europe during the Pre-Roman Iron Age. Still, an inhumation grave 
of a young man in East Yorkshire, England, was furnished with 16 bone points. The way they were placed in the grave gave rise to the interpretation that they had been used as skewers to pin together a wrapper, covering the body. It may, however, be that this was a secondary use of the points (Olsen 2003, 109). Furthermore, Klaus Raddatz listed three burials from Brandenburg, Germany and one from the Gdansk region in Poland each furnished with one or two bone points (Raddatz 1954, 64-65). Since, unfortunately, all these graves were cremations, they do not contribute to the use of the points.

This leaves us with the finds from the wetlands. Often these points were found during peat cutting or mudding. Therefore, in many cases the contexts are not well illuminated. Two particular finds stand out in this connection, the finds in the Hjortspring bog (Rosenberg 1937) and at Krogsbølle (Kjær 1901) on the Danish isles Als and Fyn. In both cases the points are parts of larger weapon deposits, and in both cases some of them are still mounted on wooden shafts. Thus in these cases the interpretation as spear heads seems unquestionable.

But does this apply for all bone points found in wet lands? Mogens Bo Henriksen has mapped the finds of such points around an inlet on Northern Fyn and interprets the distribution of these solitary finds as evidence of coastal fish hunting (Henriksen 1997). The argument seems convincing and gets support from the earlier mentioned Norwegian rock-shelter finds. Furthermore, fish spearheads would eventually be shafted very much in the same way as would weapon spearheads. Thus the bone points seem at least to have had two functions, as a weapon and as an implement for fishing and hunting.

\section{Bone and antler points as weapons}

The final question is how the bone points were used as a weapon. As mentioned earlier, the choice of raw material is usually considered as an evidence of a lack of better resources (i.e. metal). The bone points are therefore generally seen as of less worth and therefore being more disposable than their metal counterparts. Hence, they are often interpreted as javelins rather than spearheads (e.g. Randsborg 1995, 54-56), i.e. a weapon to be used before engaging in close combat.

I have previously argued that there are signs that at least some of the bone points were attributed a higher value. This was based on the fact that some of the bone and antler points are carefully polished and ornamented (Martens 2011, 157) (figs. 4a and b). This indicates that these particular points were seen as personal weapons, perhaps even carrying the marks and symbols of a social or otherwise symbolic meaning. Such ornaments are usually found on weaponry but not on ordinary tools. 

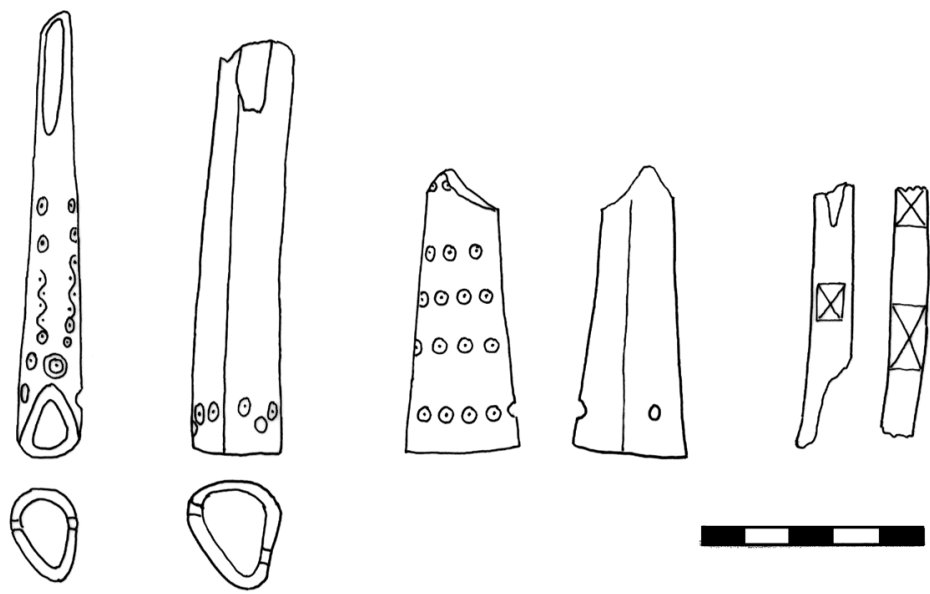

Fig. 4a. Ornamented bone points from Borrebjerg (after Martens 2011, fig. 8).

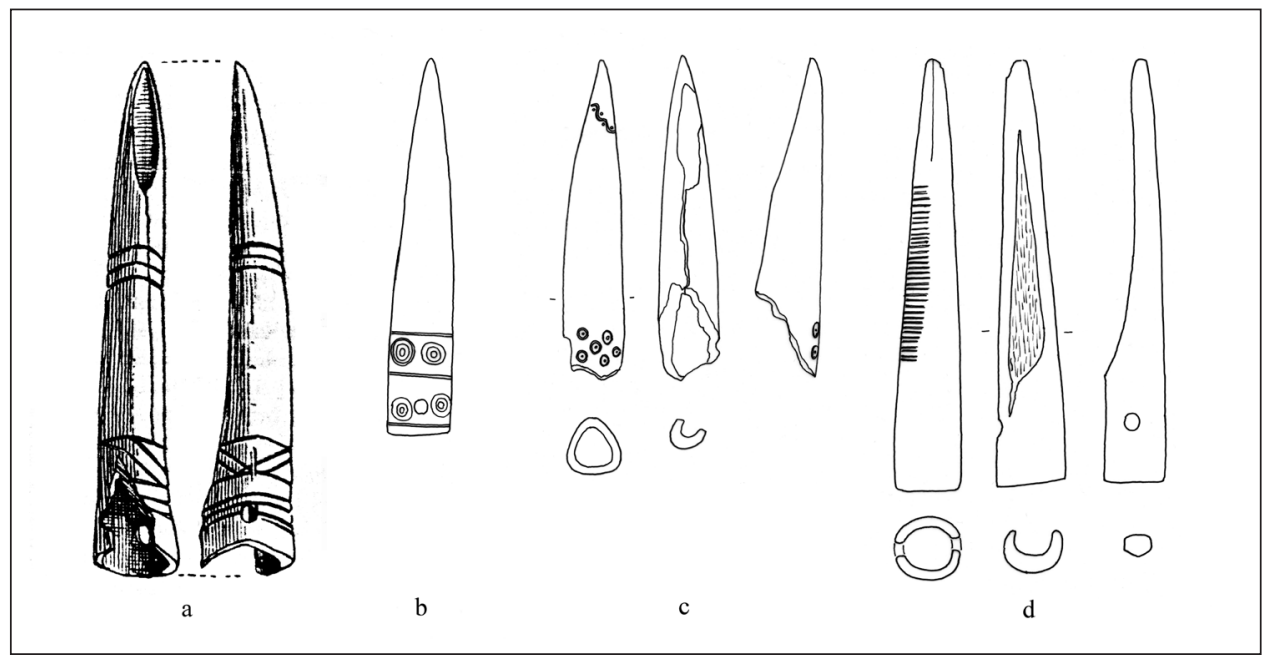

Fig. 4b. Ornamented bone and antler points from a; Pritzerber See, b; Hjortspring, c and d; Segeå and (after Raddatz 1954, fig 1.3; Martens 2011, fig. 11a; Martens 2001, figs. 11a and 13f).

Furthermore, referring to a study by Jon Bryant Finney (2006), I have pointed out that since the weight of a bone point usually is relatively low, it would not give the javelin sufficient balance in the glide. Though this could have been compensated by shaping the shaft in such a way that the balance of the javelin would be ideal, the factual evidence, i.e. the shafted points from Hjortspring and Krogsbølle do not support such an assumption (Martens 2011, 158). 

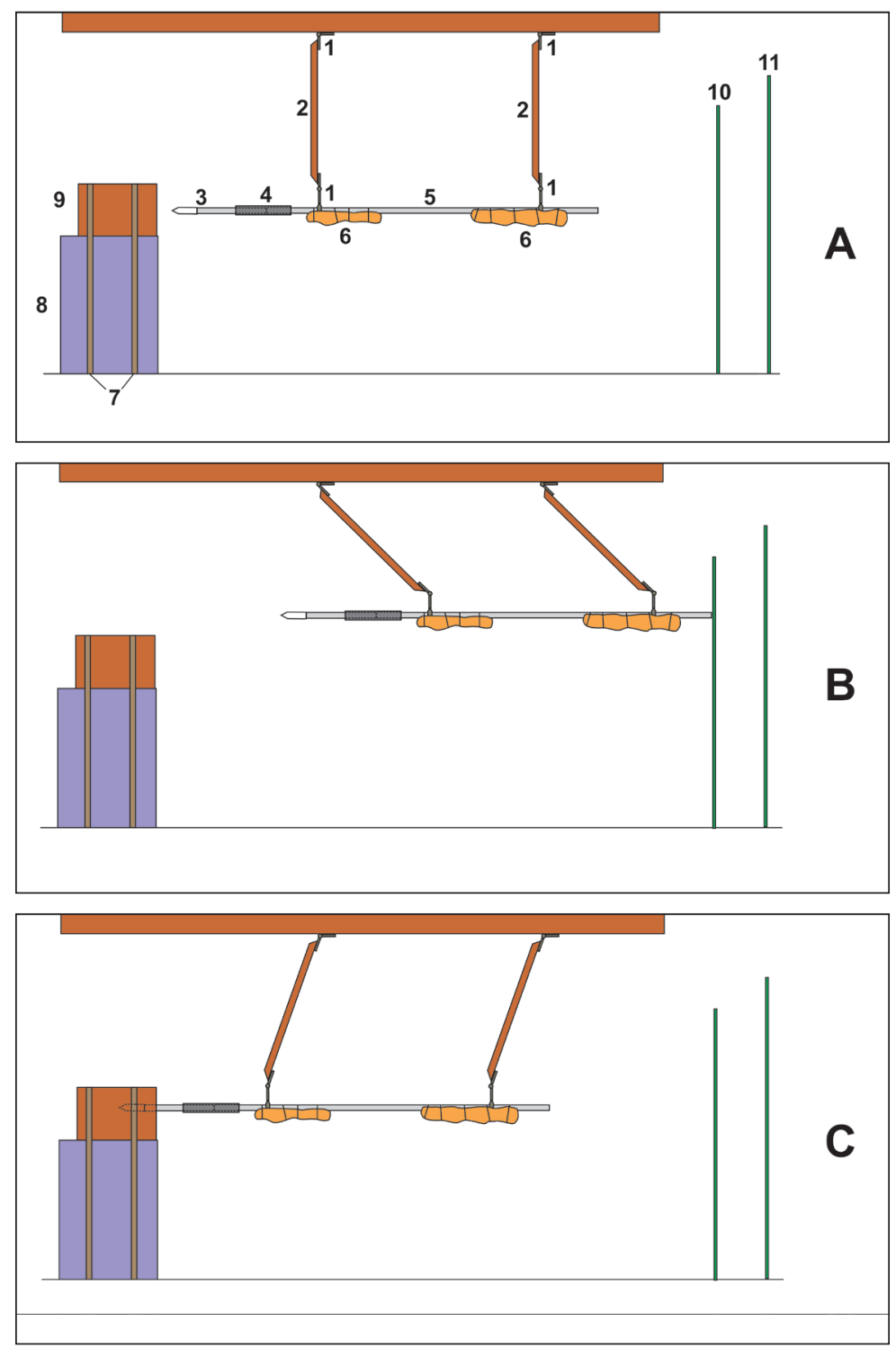

Fig. 5. The experimental set up of Torben Schatte (after Schatte 2013, fig. 18).

To these arguments may be added that Torben Schatte in a series of controlled experiments has demonstrated that bone points in fact are effective weapons when shafted correctly, and he therefore concludes that they were by no means "ad hoc weaponry" (Schatte 2013, 95, fig. 18). In his experiment (fig. 5) the points were used as spearheads, and though the iron tipped spears in average penetrated about $30 \%$ deeper into the target, by means of the same thrust power the bone points proved to be not only efficient but also durable. 
Finally, it is time to call a witness. In the year $480 \mathrm{BC}$, Xerxes crossed the Hellespont with a formidable force in order to subdue the European part of the Greek world. His army was made up of contingents from all parts of the Persian Empire as well as from their allies. The Greek historian Herodotus has described this impressive show of force in detail, mentioning how each contingent set itself apart from the others in weaponry, armour as well as fighting techniques. About the Ethiopians he wrote;

"The Ethiopians had skins of leopards and lions tied upon them, and bows made of a slip of palm-wood, which were of great length, not less than four cubits, and for them small arrows of reed with a sharpened stone at the head instead of iron, the same stone with which they engrave seals: in addition to this they had spears, and on them was the sharpened horn of a gazelle by way of a spear-head, and they had also clubs with knobs upon them. Of their body they used to smear over half with white, when they went into battle, and the other half with red"

(here quoted from the online translation on the Gutenberg-project https:// www.gutenberg.org/ebooks/2456)

This quotation is especially interesting for two reasons; first of all it demonstrates that even in the Mediterranean world points of bone or antler could be used as weapons during what we in Northern Europe call the Early Pre-Roman Iron Age; secondly since Herodotus during his account of the two opposing armies explicitly distinguished between spears and javelins, there seems to be no doubt that the Ethiopian did use spears with antler points. Thus we know that antler and bone points have been used as spearheads, even alongside spears with metal points. Since weapon technology is often shared by large areas, this would indicate that the contemporary points of bone and antler found in martial contexts in Northern Europe were used in a similar way. That there was a connection between Northern Europe and the Mediterranean World during the Early Pre-Roman Iron Age and that it also was expressed in weaponry and fighting order has already been suggested by other authors (e.g. Kaul 1988; Randsborg 1995).

\section{Concluding remarks}

The present survey demonstrates that we are still far from completely understanding the use of this particular artefact type which seems to have served more than one function. The best documented ones are as combat weapons, i.e. spears, and as fishing and hunting implements, but even a function as lip-work 
awls or other kinds of tools cannot be ruled out. Due to their relatively simple appearance and their usual find contexts, it is likely that points of bone and antler may be overlooked in some areas and therefore their actual distribution is uncertain. The question of their dating has not been an issue in this paper, but even here there may be room for future research, since bone points have been reported found in context dating from the Neolithic to the Middle Ages.

\section{Bibliography}

Althin, Carl-Axel. 1951. "Einige schonische Funde aus der keltischen Eisenzeit." Meddelanden LUHM 1950/51:151-156.

Bergsvik, Knut Andreas. 2017. "Caves and Rockshelters in Iron-Age Coastal Norway. At the Margins of the Society?" In Life on the Edge: Social, Political and Religious Frontiers in Early Medieval Europe, edited by Sarah Semple, Celia Orsini and Sian Mui, 317-334. Neue Studien Sachsenforschung, 6. Braunschweig: Braunschweigisches Landesmuseum.

Brøgger, Anton Wilhelm. 1910. "Vestnorske hulefund fra ældre jernalder.“ Bergen museums Aarbog 1910, nr. 16: 1-22.

Finney, Jon Bryant. 2006. Middle Iron Age Warfare of the Hillfort Dominated Zone c. 400 BC to c. 150 BC. BAR British Series 423, Oxford: Archaepress.

Haarnagel, Werner. 1979. Die Grabung Feddersen Wierde. Methode, Hausbau, Siedlungs- und Wirtschaftsformen sowie Sozialstruktur. Feddersen Wierde. Die Ergebnisse der Ausgrabung der Vorgeschichtlichen Wurt Feddersen Wierde bei Bremerhaven in den Jahren 1955 bis 1963. Band II. Wiesbaden: F Steiner.

Henriksen, Mogens Bo. 1997. "Fiskeri og kystjagt på Nordfyn i jernalder, vikingetid og tidlig middelalder." Sletten. Årsskrift for nordfynsk lokal- og kulturhistorie: 5-14.

Kaul, Flemming. 1988. Da våbnene tav. Hjortspringfundet og dets baggrund. København: Arnold Busck.

Kjær, Hans. 1901. "To nye Mosefund fra Jærnalderen." In Aarbøger for Nordisk Oldkyndighed og Historie 1901, 26-54. København: Nordiske Oldskriftselskab.

Martens, Jes. 2001. "A Wooden Shield-Boss from Kvärlöv, Scania. Some Remarks on the Weaponry of the Early Pre-Roman Iron Age in Northern Europe and the Origin of the Hjortspring Warriors." In Trans Album Fluvium. Forschungen zur vorrömischen, kaiserzeitlichen und mittelalterlichen Archäologie edited by M. Meyer, Festschrift für Achim Leube zum 65. Geburtstag, 135-159. Rahden: Vlg Marie Leidorf.

Martens, Jes. 2011. "Weapons, armaments and society. The Pre-Roman Iron Age on Zealand and in Scania." In The Iron Age on Zealand. Status and 
Perspectives, edited by L. Boye, 147-174. København: Det kongelige Nordiske Oldskriftselskab, Nationalmuseet.

Nummedal, Anders. 1913. Bjørneremsfundet. Forhistoriske hulefund fra Mien i Romsdalen. Det kongelige norske videnskabers selskabs skrifter 1912, nr. 12, Trondhjem.

Olsen, Sandra L. 2003. “The bone and antler artefacts: their manufacture and use." In Fiskerton. An Iron Age timber causeway with Iron Age and Roman votive offerings edited by N. Field and M. Parker Pearson, 92-111. Oxford: Oxbow Books.

Randsborg, Klaus. 1995. Hjortspring. Warfare \& Sacrifice in Early Europe. Aarhus: Aarhus University Press.

Roes, Anna. 1963. Bone and Antler Objects from the Frisian terp mounds. Haarlem: H. D. Tjeenk Willink.

Rosenberg, Gustav. 1937. Hjortspringfundet. Nordiske fortidsminder III-1, 5-102. København:Gyldendal.

Schatte, Torben. 2013. "Tüllenspitzen aus Knochen und Geweih." Mitteilungen der Berliner Gesellschaft für Anthropologie, Ethnologie und Urgeschichte 34: 91-110

Schoknecht, Ulrich. 1982. "Mecklenburgische Knochenlanzenspitzen aus germanischer Zeit." Bodendenkmalpflege in Mecklenburg, Jahrbuch 30: 47-66.

\section{De la Ultima Thule la Hellespont - câteva observații despre vârfurile din os în perioada epocii fierului}

\section{Rezumat}

Pornind de la două descoperiri de vârfuri din os din Norvegia, se propune spre discuție distribuția și utilizarea acestui tip de artefact. Vârfurile din os și corn de cerb sunt frecvent întâlnite în așezările și în zonele umede ale Europei de Nord. $\mathrm{Cu}$ toate acestea, distribuția exactă a respectivului tip de artefact este greu de determinat, deoarece designul său modest îl face ușor de trecut cu vederea. Acesta este și motivul pentru care este privit de obicei ca un semn al sărăciei și ca o piesă de a doua mână. Se pare că tipul de artefact a avut mai multe funcționalități. Ele puteau servi în calitate de unelte, de ustensile de pescuit și vânătoare sau ca arme de luptă. În ceea ce privește funcționalitatea de armă, se susține că vârfurile din os și corn de cerb erau arme prețuite și eficiente care, probabil, au servit, mai degrabă, ca sulițe decât în calitate de lance. Acest fapt este confirmat și de surse scrise antice.

Cuvinte cheie: epoca preromană a fierului, vârfuri din os, vârfuri din corn de cerb, arme, sulițe.

\section{Jes Martens,}

Museum of Cultural History, University of Oslo, Norway.

Email: Jes.martens@khm.uio.no 